\title{
Effect of Integrated Nutrient Management on Vegetative Growth, Fruit Yield and Quality of Fruit Crops
}

\author{
Ritik Chawla ${ }^{1}$ and Ramesh Kumar Sadawarti ${ }^{2 *}$ \\ ${ }^{1}$ SAGR, Lovely Professional University, Phagwara, Punjab, India \\ ${ }^{2}$ Department of Horticulture, SAGR, Lovely Professional University, Phagwara, Punjab, India \\ *Corresponding author
}

\begin{abstract}
A B S T R A C T
Continuous use of chemical fertilizers without organic sources poses soil health issues whereas organic manures using alone without inorganics could not be able to fulfill the requirement of high nutrient demanding crops due to the bulk and slow-acting nature of these organic fertilizer sources. However, neither organic fertilizers nor inorganic fertilizers alone can maintain productivity. The major yield limiting factors in crops production in Indian soils are NPS deficiencies. So, the option is to concentrate on alternate system like integrated nutrient management to maintain the productivity of soils where INM is promising strategy that aims to achieving harmony in the conjoint use of all resources like organic manures, bio-fertilizers, vermicompost, chemical fertilizers and other non conventional sources of plant nutrients. Before the establishment of Green Revolution majorly millets were grown and only organic manures were used, but after the Green revolution use of synthetic fertilizers increased day-by-day. Now by seeing the advantages of organic manures in crop plants are drawing the interest of soil scientists and farmers all over the world. Organic manures are the valuable resources in most of the agricultural soils as they provide not only the nutrition but also replenish the organic matter content in soils. Many studies showed that INM activities for sustainable agriculture around the world may be creative and environmentally friendly. In this review paper we will study the impact on characters of growth, quality and yield of fruit plants of integrated nutrient management.
\end{abstract}

\section{Keywords}

INM, Organic manures, Biofertilizers, Fruit

Production,

Sustainable agriculture

\section{Article Info}

Accepted:

17 September 2020 Available Online:

10 October 2020

\section{Introduction}

To accomplish the nutrient requirement for crops, chemical fertilizer is mostly used. Due to the hazardous effect on fruit quality, on soil, water and environmental conditions there is a need to adopt an integrated approach to supply all the essential nutrients to the plants without harming the soil and environment. By using the both of inorganic and organic fertilizers to enhance the production of crops is known as Integrated Nutrient Management. In basic words, the INM method means the use of artificial fertilisers in addition with crop residues, organic manures, bio-fertilizers and other sources related to biological in equal amount of proportion (Mahajan et al., 2009). Now a day's Integrated Nutrient 
Management gaining significance in the field of fruit production as it maintains the soil health, minimize the use of chemical/artificial fertilizers or environmental pollution and provide most of the nutrients to the plants at low cost (Jamwal et al., 2018) and it also prevents the loss of nutrients from plants as well as the suppression of certain insect-pests and diseases (Gaur, 2001).

INM method is also useful to those farmers who can't bear the expensive chemical fertilization to provide nutrients for any crop. Furthermore, it aims to improve the condition of land by improving their biological, mechanical, hydrological and physical properties in order to increase agricultural productivity and reduce the depletion of soil (Saikia et al., 2015). Now there is a stronger awareness that integrated nutrient management will not only increase production but at the same time maintain soil quality. Its activities use FYM, soil improvement, farm waste, crop residues, composts, green manures, chemical and natural fertilizers, intercropping, cover crops, tillage maintenance and drainage systems for water management (Wu and Ma, 2015). This approach also involves innovative strategies like deep fertilizers placement and the use of urea coatings, which have been designed to increase plant uptake and reduce nutrient losses (Saikia et al., 2015). These activities allow producers to concentrate on sustainable planning and to take environmental implications into greater consideration rather than only relying on returns. Integrated nutrient management can be achieved by adopting some practices such as use of organic manures like FYM, vermicompost, bio-fertilizers along with the combination of inorganic fertilizers.

Farmyard manure (FYM) supplies many nutrients especially micronutrients and they are also a good source of organic matter.
Manure increases organic matter of soil, improve soil structure or drainage in finetextured clay soil, increases the WHC (water holding capacity of soil), serves as a source of slow release nutrients, reduces water or wind erosion, encourages the growth of earthworm and all other beneficial soil microorganisms (Rai, 2014).

Vermicompost is another component of INM which contains high organic carbon levels. It plays a major role in fertility of the soil and contains all the necessary nutrients in sufficient amount which make it as a complete and healthy plant food. It also improves soil fertility and quality by improving its chemical, biological and physical properties, growth-promoting substances and micro-organisms which is beneficial for soils or it has also the property of inhibiting pathogenic microbes. Application of vermicompost increases crop yield, nutrient status and nutrient uptake. The beneficial role of vermicompost has been also reported in fruit crops viz., strawberry (Singh et al., 2008a), papaya (Acevedo and Pire, 2004), banana (Athani and Hulamani, 2000), guava (Athani et al., 2007), bean plants (Mahmoud and Gad, 2020), pineapple (Mahmud et al., 2019).

Bio-fertilizers are also another component of INM containing living organisms which increases the supplements of primary nutrients to the main crop. These are differ from chemical or organic fertilizers in such a way, that it cannot supply direct nutrition to plants and they are the culture of special or specific fungi and bacteria, comparatively simple and have a less cost of installation. Bio-fertilizer increases overall development of vegetative growth parameters like in higher growth rates, stem girth, also in yield development, fruit quality, fruit weight, TSS of fruit, and it also reduces acidity as compared to chemical fertilizer (Alam and 
Seth., 2014). Bio-fertilizers have the ability to solubilises 30-50 kg $\mathrm{P}_{2} \mathrm{O}_{5}$ /ha/year, fixes 20$200 \mathrm{~kg} \mathrm{~N} / \mathrm{ha} /$ year (Hazarika and Ansari, 2007). The beneficial role of bio-fertilizers has been reported in fruit crops viz. strawberry (Kumar et al., 2019) and mango (Poonia et al., 2018).

Thus, INM system can increase productivity of crops as well as improves condition of soil through synergistic effects. Major components of INM are as follows:

Incorporating soil fertility maintaining crops such as legumes, green manures etc.

Recycling the crop residues.

Using organic manures viz., vermicompost, FYM, biogas, compost, poultry manure, Phospho-compost, slurry, Press mud cakes.

Efficient genotypes.

Balanced use of nutrients from fertilizers according to the particular crop requirements and aims to increase yields.

Application of biological substances (Jat et al., 2015).

\section{Effect of inm on yield, growth and quality of fruit crops}

\section{Mango}

Zonayet et al., (2020) reported that In Khagrachari site, the highest mango yield $22.30 \mathrm{~kg} /$ plant was in $\mathrm{T}_{4}$ treatment $(150 \%$ of $\mathrm{T}_{2}$ ). In Bandarban site, the highest mango yield $48.25 \mathrm{~kg} /$ plant found in $\mathrm{T}_{3}$ treatment (125\% of $\mathrm{T}_{2}$ ). In Rangamati site, the highest mango yield $23.10 \mathrm{~kg} /$ plant found in $\mathrm{T}_{4}$ treatment $\left(150 \%\right.$ of $\left.\mathrm{T}_{2}\right)$.

In most cases the significant difference in yields were found in $\mathrm{T}_{4}$ treatments in three districts. In current studies the fruit yield increased might be because of the optimum nutrient supply with combined use of chemical bio-organic and fertilizers in rhizosphere.

Nehete and Jadav (2019) reported that the highest TSS (21.43\%), total sugar (18.82\%), maximum ascorbic acid (42.76 $\mathrm{mg}$ ), reducing sugars $(8.80 \%)$ of Mango cv. Amrapali was observed in application of $\left(\mathrm{T}_{13}\right) \mathrm{N} 70 \%+\mathrm{P}_{2} \mathrm{O}_{5}$ $85 \%+$ PSB + Azotobacter from the other treatments. While it was noticed that the higher yield $(54.00 \mathrm{~kg} /$ tree $)$ comes under application of $\left(\mathrm{T}_{10}\right) \mathrm{N} 85 \%+\mathrm{P}_{2} \mathrm{O}_{5} 85 \%+$ $\mathrm{PSB}+$ Azotobacter which was closely related with $85 \% \mathrm{~N}+100 \% \mathrm{P}_{2} \mathrm{O}_{5}+\mathrm{PSB}+$ Azotobacter $\left(\mathrm{T}_{8}\right)$ and $70 \% \mathrm{~N}+85 \% \mathrm{P}_{2} \mathrm{O}_{5}+$ $\mathrm{PSB}+$ Azotobacter $\left(\mathrm{T}_{13}\right)$.

Gautam et al., (2012) observed that in cv. Sunderja the treatment $\mathrm{T}_{8}$ containing $\mathrm{N} 500 \mathrm{~g}$ $+\mathrm{P} 250 \mathrm{~g}+\mathrm{K} 250 \mathrm{~g} /$ tree + vermicompost 10 $\mathrm{kg}+50 \mathrm{~kg}$ FYM enhances the yield contributing parameters such as the number of fruits/panicle, fruit yield; the fruiting parameters such as the fruit width, length, weight and pulp weight or vegetative growth parameters like the maximum canopy or plant spreading (E-W) and (N-S), plant height as against to other treatments.

Yadav et al., (2011) found that the physical parameters of cv. Amrapali i.e. highest fruit width $(6.62$ and $6.48 \mathrm{~cm})$, fruit length $(9.88$ and $10.08 \mathrm{~cm})$, weight (151.25 and $153.00 \mathrm{~g}$ ), stone weight (26.45 and $26.62 \mathrm{~g}$ ), pulp weight (97.06 and $97.08 \mathrm{~g}$ ), maximum TSS (23.72 and $23.91^{\circ}$ Brix), pulp: stone ratio (3.693 and 3.694), number of flowers (1710.67 and 1756.00), sex ratio (0.690 and 0.691), number of fruits per tree (163.33 and 184.67), fruit set (194.67 and 201.33) and fruit yield (25.00 and $26.72 \mathrm{q} / \mathrm{ha}$ ) were observed under the treatment of $\mathrm{T}_{8}$ containing (RDF of NPK + PSB + Azotobacter + vermi-compost + paclobutrazol $+\mathrm{Fe}+\mathrm{Zn}$ ) was closely followed by $\mathrm{T}_{12}(\mathrm{RDF}$ of NPK + PSB + Azotobacter + 
$\mathrm{BD}$ compost + paclobutrazol $+\mathrm{Fe}+\mathrm{Zn}$ ) over the two experimental years.

Singh et al., (2015) concluded that in Mango Fruit cv. Himsagar the $\mathrm{T}_{6}$ treatment containing $500 \mathrm{~g} \mathrm{~N}: 250 \mathrm{~g} \mathrm{P}: 250 \mathrm{~g} \mathrm{~K}$ per tree per year $+250 \mathrm{~g}$ Azospirillium $+50 \mathrm{~kg}$ FYM recorded the highest tree height $(108.00 \mathrm{~cm})$, fruit weight $(263.10 \mathrm{~g})$, plant spread in N-S $(105 \mathrm{~cm})$ and $\mathrm{E}-\mathrm{W}(123 \mathrm{~cm})$ direction, tree volume $\left(85.95 \mathrm{~m}^{3}\right)$, total number of fruits (234.12) and yield per tree $(58.56 \mathrm{~kg})$ than all other treatments.

Hasan et al., (2013) reported that in Mango Fruit cv. Himsagar by analyzing all the results, the application of vermicompost in combination with $\left(\mathrm{T}_{7}\right) 850 \mathrm{~g}: 425 \mathrm{~g}: 1000 \mathrm{~g}$ $\mathrm{NPK}+250 \mathrm{gm} \mathrm{PSB}+$ Azospirillum $250 \mathrm{gm}+$ $100 \mathrm{gm}$ borax $+\mathrm{ZnSo}_{4} 100 \mathrm{gm} /$ tree / year shows a substantial improvement in fruit length $(9.53 \mathrm{~cm})$, weight $(273.20 \mathrm{~g})$, highest TSS $\left(21.57^{\circ}\right.$ Brix), pulp weight (180.20), total sugar $(11.32 \%)$, ascorbic acid (25.68 mg per 100 gram) and pulp content (65.96\%) and lowest acid content than all other treatments.

Talang et al., (2017) revealed that in Mango Fruit cv. Himsagar with treatment containing half (1000:500:1000 g NPK/tree) $+50 \mathrm{~kg}$ FYM + Azospirillium (250 g) + $100 \mathrm{~g}$ potassium mobiliser $\left(\mathrm{T}_{6}\right)$ recorded maximum girth of stem $(64.91 \mathrm{~cm})$, plant height $(5.79$ $\mathrm{m})$, tree spread in $\mathrm{N}-\mathrm{S}(5.46 \mathrm{~m})$ and $\mathrm{E}-\mathrm{W}$ $(5.63 \mathrm{~m})$ direction while maximum fruit number $(230.31 /$ tree $)$, yield $(60.22 \mathrm{~kg})$, weight (261.48 g), fruit TSS (19.66 ${ }^{\circ}$ Brix), total sugars $(16.48 \%)$, ascorbic acid (33.56 mg per 100 gram pulp), â-carotene $(6935 \mu \mathrm{g}$ per 100 gram pulp) recorded under $\mathrm{T}_{8}$ consisting of half (1000:500:1000 g $\mathrm{NPK} /$ tree) $+50 \mathrm{~kg} \mathrm{FYM}+5 \mathrm{~kg}$ vermicompost $+100 \mathrm{~g}$ potassium mobiliser as compared to other treatments.
Sharma and Sharma (2016) showed that in Mango Fruit cv. Amrapali application of 520g $\mathrm{N}: 160 \mathrm{~g}$ P: $450 \mathrm{~g} \mathrm{~K}$ per plant along with $25 \mathrm{~kg}$ vermicompost $+2.5 \mathrm{~kg}$ Oil cake + PSB + VAM + Azotobacter + TV (100g each) recorded maximum crown height $(78.3 \mathrm{~cm})$, crown length $(197.4 \mathrm{~cm})$, crown width E-W $(248.4 \mathrm{~cm})$, crown width $\mathrm{N}-\mathrm{S}(251.7 \mathrm{~cm})$, shoot length $(16.1 \mathrm{~cm})$, number of panicle $(40.0)$ and length of panicle $(39.7 \mathrm{~cm})$ than control and other treatments.

\section{Peach}

Solanki et al., (2020) observed that the yield $(20.16 \mathrm{~kg}$ per tree) and fruit set $(87.70 \%)$ of Peach cv. July Elberta was identified considerably higher by the application of $\mathrm{RDF} 75 \%+15 \mathrm{~kg}$ vermicompost/tree.

It was also found that cumulative breadth of fruit $(61.89 \mathrm{~mm})$, highest length of fruit $(64.06 \mathrm{~mm})$, total sugars $(7.51 \%)$, TSS $(13.33$ $\left.{ }^{\circ} \mathrm{B}\right)$ and weight (129.51 g) under RDF $75 \%+$ $15 \mathrm{~kg}$ vermicompost per tree.

\section{Pomegranate}

Gajbhiye et al., (2020) concluded that the higher fruit set (84.39\%), number of flowers (204.75), fruit wt. (244.82 g) and yield (41.21 $\mathrm{kg} / \mathrm{tree}$ ) of Pomegranate were recorded with treatment $\mathrm{T}_{7}$ (INM: Compost + Solubilizers + RDF + Umber (Ficus racemosa) Rhizosphere hybridised soil) followed with the treatment $\mathrm{T}_{6}$ (INM : compost + solubilizers + RDF + Antibiotics) with values number of flowers (189.50), maximum fruit set (82.08 per cent), the yield (37.53 kg tree ${ }^{-1}$ ) and the maximum weight (240.49 g) over other treatments under study whereas, the lower (61.25) number of flowers, minimum fruit set $(68.15 \%)$, weight $(188.38 \mathrm{~g})$ and yield $\left(9.08 \mathrm{~kg}\right.$ tree $\left.^{-1}\right)$ were observed under the absolute $\mathrm{T}_{1}$ control. 


\section{Banana}

Patil and Shinde (2013) revealed that in banana cv. Ardhapuri the highest leaf number (32.30), maximum leaf area i.e. $17.93 \mathrm{~m}^{2}$, girth $(81.34 \mathrm{~cm})$ and height $(190.84 \mathrm{~cm})$ were observed by the application of $\mathrm{T}_{3}$ containing $50 \%$ RDF + Farmyard manure + PSB $50 \mathrm{~g}+$ $50 \mathrm{~g}$ Azotobacter + VAM 250 gram per plant. Likewise, the yield contributing factors like yield (85.80 t/ha) and bunch wt (19.31 kg) were found higher in $\mathrm{T}_{3}$. The treatment of RDF $50 \%$ + Farmyard manure + PSB $50 \mathrm{~g}+$ Azotobacter $50 \mathrm{~g}+250 \mathrm{~g}$ VAM per plant were found to be advantageous for the yield and growth of banana.

Kuttimani et al., (2013) with their studies concluded that higher corm diameter (79.17 and $79.17 \mathrm{~cm}$ ), root numbers (242.57 and 233.00) and corm volumes (4.10 and 4.73 lit plant $^{-1}$ ) were observed throughout 2010-11 and 2011-12 respectively by the application of RDF $100 \%$ + Wellgro soil $40 \%$. Similarly, there has been a substantial increase over RDF $100 \%$ with either $40 \%$ Wellgro soil or $10 \mathrm{~kg} \mathrm{FYM} \mathrm{plant}^{-1}$ over both the experimental years with growth parameters such as the index of the leaf area and the crop growth, net assimilation rate, relative rate of growth, the absolute rate of growth and physiological parameters like nitrate reductase activity, soluble protein and total chlorophyll content. Hence, integrated nutrient management approaches have proved to be the most appropriate choice for optimising banana growth and physiological parameters.

Bhalerao et al., (2009) observed in banana cv. Grand Naine the treatment containing $100 \%$ $\mathrm{RDF}+\mathrm{FYM} 10 \mathrm{~kg}+$ PSB $25 \mathrm{~g}+$ Azosprillum $25 \mathrm{~g}$ were beneficial for the yield of banana which was closely related to treatment containing 50\% NPK from inorganic and biofertilizers and $50 \%$ NPK through organic i.e. Green manure + FYM. Furthermore, it had been recognized that organic manure alone was not effective for optimum production relative to integrated nutrient management.

Nayyer et al., (2014) revealed that in Banana cv. Grand Naine the pseudo girth $(67.98 \mathrm{~cm})$, stem height $(150.27 \mathrm{~cm})$, inflorescence length $(118.50 \mathrm{~cm})$, leaf numbers (34.66) were higher in plants treated with RDF $100 \%+$ Azospirillum $50 \mathrm{~g}+T$. harzianum $50 \mathrm{~g}+50 \mathrm{~g}$ PSB /plant with early flowering (253.33 days) or flowering to bunch harvesting (110.00 days) as opposed to other treatments. Similar treatment was also beneficial for increasing the fingers numbers/hand (19.33) or per bunch (160.00), bunch wt. (24.50 kg), finger wt. $(140.00 \mathrm{~g})$, diameter $(15.20 \mathrm{~cm})$, length $(20.33 \mathrm{~cm})$, pulp percentage $(82.17 \%)$, total sugars $(18.66 \%)$, TSS $\left(19.26^{\circ} \mathrm{B}\right)$ and pulp: peel ratio (4.60) with minimum titratable acidity $(0.40 \%)$

Syed (2009) stated that in banana cv. Ardhapuri the best application for the development of the bunch wt. (18.4 kg) and yield (81.8 ton/ha) was N 200g $+\mathrm{P}_{2} \mathrm{O}_{5} 150 \mathrm{~g}+$ $\mathrm{K}_{2} \mathrm{O} 200 \mathrm{~g}+$ organic slurry 6 litres/plant among different combinations. This treatment also increased NPK availability in soil or boosted the nutritional level in leaf tissues index.

\section{Papaya}

Kanwar et al., (2020) studied that among the all treatment highest fruit number (78.33), yield $(71.32 \mathrm{~kg} /$ plant $)$, fruit weight (1486 g) and length $(22.66 \mathrm{~cm})$ of Papaya fruit cv. Red lady was observed under treatment $\mathrm{T}_{8}(75 \%$ $\mathrm{RDF}+100 \mathrm{~g}$ Azotobacter $+100 \mathrm{~g}$ PSB+ Vermicompost $10 \mathrm{~kg}$ per plant) or it was closely followed by $\mathrm{T}_{9}$ and $\mathrm{T}_{7}$ treatment i.e. number of fruits (74.33 and 71.00), fruit yield (67.86 and $66.93 \mathrm{~kg})$, fruits length (19.33 and 21.33) and fruit weight were (1423.33 $\mathrm{g}$ and $1340.00 \mathrm{~g}$ ) respectively whereas less number 
of fruits or yield have been registered in $\mathrm{T}_{0}$ (RDF + Control).

Singh and Varu (2013) concluded that in papaya cv. Madhubindu the treatment comprising of half RDF (N $100 \mathrm{~g}+\mathrm{P} 100 \mathrm{~g}+$ $\mathrm{K} 125 \mathrm{~g} /$ plant $)+$ PSB $2.5 \mathrm{~g} / \mathrm{m}^{2}+$ Azotobacter $50 \mathrm{~g} / \mathrm{plant}\left(\mathrm{T}_{8}\right)$ have been found to have increased the yield and growth parameter with the greatest survival rate (98.67 percent), length of fruit $(30 \mathrm{~cm})$, weight $(1670 \mathrm{~g})$, girth $(22 \mathrm{~cm})$, number of fruits (45.33), yield per plant, hectare or plot $(78 \mathrm{~kg} / 313 \mathrm{~kg} / 259.97 \mathrm{t}$, respectively). Similarly, quality factors like TSS, total, reducing and non-reducing sugars $\left(15.47^{\circ}\right.$ Brix, $13.58, \quad 11.10$ and $2.43 \%$, respectively) had been noted maximum in the same application. It was however found to be equivalent to $1 / 4 \mathrm{RDF}+3 / 4$ Jivamrut $\left(\mathrm{T}_{13}\right)$. Low output for all parameters has also been observed in control.

Singh et al., (2008b) observed that in papaya cv. Surya the highest leaf numbers (18.73), stem girth $(0.26 \mathrm{~m})$, average weight $(0.85 \mathrm{~kg})$, number of fruits (46), thickness of pulp (3.5 $\mathrm{cm})$, TSS $\left(15.8^{\circ} \mathrm{B}\right)$, vit. A (2280 IU per100 gram pulp), shelf life (12 days) were concluded with $75 \%$ RDF + bacteria culture of rhizosphere $+25 \%$ vermicompost treatment whereas the mean height of the plant $(185.35 \mathrm{~cm})$ and the length of the petiole $(8.42 \mathrm{~cm})$ comes under $100 \%$ RDF alone. The $75 \%$ RDF + bacteria culture of rhizosphere+ $25 \%$ vermicompost was considered more superior and commercially feasible than any other treatments.

Tandel et al., (2014) revealed that in Papaya $\mathrm{cv}$. Red Lady the treatment $\mathrm{T}_{6}$ containing of $50 \%$ RDN from inorganic fertilizer $+25 \%$ RDN from (bio compost + castor cake, respectively) suggested higher growth values like height of plant $(185.39 \mathrm{~cm})$, stem of girth $(50.51 \mathrm{~cm})$ and leaf number (44.92). And this treatment also influenced the physiological parameters viz., photosynthetic rate, transpiration rate, total chlorophyll content and leaf temperature.

\section{Kinnow}

Bakshi et al., (2018) shown that in Kinnow Mandarin the highest height of plant (14.30\%), canopy volume $(38.95 \%)$ and plant spreading direction (E-W $14.0 \%$ and $\mathrm{N}-\mathrm{S}$ $14.05 \%$ ) was reported by the treatment of $100 \% \mathrm{~N}$ as urea + Azotobacter in combination with recommended MOP and SSP. However, the yield contributing factors like width of fruit $(6.53 \mathrm{~cm})$, length $(5.84 \mathrm{~cm})$, number of fruits (165.5), volume of fruit $(191.83 \mathrm{cc})$, weight $(188.18 \mathrm{~g})$ and yield of kinnow fruit $(31.14 \mathrm{~kg})$ per plant with the applications of $\mathrm{N}$ $50 \%$ by poultry manure or $50 \%$ remaining $\mathrm{N}$ by urea in conjuction with the Azotobacter were obtained higher. It was concluded that application of $50 \%$ nitrogen as urea can be substituted by poultry manure application along with Azotobacter treatment.

\section{Acid lime}

Kumar et al., (2020) concluded that the highest length of fruit $(5.27 \mathrm{~cm})$, diameter $(4.93 \mathrm{~cm})$, number of seeds (8.17), seed weight $(1.24 \mathrm{~g})$, juice percentage $(56.94 \%)$, specific gravity (1.36), peel thickness (1.94 $\mathrm{mm})$, moisture content of peel $(84.28 \%)$ and moisture content of pulp (93.89\%) of Acid Lime were recorded under $\mathrm{T}_{12}-50 \% \mathrm{RDF}+$ $75 \%$ FYM $+75 \%$ Vermicompost + Biofertilizers (25g Azotobacter $+25 \mathrm{~g}$ PSB + $150 \mathrm{~g}$ VAM) and the minimum results comes under control.

Lal and Dayal (2014) announced in Acid Lime fruit the treatment containing $\mathrm{T}_{6}(50$ per cent $\mathrm{RDF}+50$ per cent by goat manure) was superior from the remaining treatments showing the maximum yield $(7.58 \mathrm{~kg} / \mathrm{tree})$ and growth of fruit with the highest length of 
fruit $(4.43 \mathrm{~cm})$, weight $(35.71 \mathrm{~g})$ and diameter $(3.99 \mathrm{~cm})$ registered under $\mathrm{T}_{6}$. Similarly, the maximum TSS $(10.42 \%)$, juice $(43.37 \%)$ and ascorbic acid content $(86.33 \mathrm{mg}$ per 100 gram juice) with less number of seeds (1.15 per cent) and acidity content (6.06 per cent) were also generated in the same procedure.

\section{Lemon}

Ghosh et al., (2020) concluded that the considerably highest flowers number of Lemon cv. Assam Lemon per plant was recorded (399, 371.67 and 250.33) in $\mathrm{N}_{4}$ treatment containing $(75 \%$ RDF +VAM + Azotobacter + Vermicompost) and the lowest flowers number $(360,386.33$ and 224.33) were seen in Vermicompost treatment $\left(\mathrm{N}_{3}\right)$ at Mrig, Ambe and Hasth bahar respectively. Bio-fertilizer's role in fixing nitrogen from atmosphere and VAM in phosphorus solubilization is responsible for preserving healthier environment or soil that was eventually reflected in the tree flowering. It also reported the substantially highest fruit yield $(7.67 \mathrm{~kg}, 13.83 \mathrm{~kg}$ and $2.14 \mathrm{~kg} /$ plant $)$ in treatment with $\mathrm{N}_{4}$.

Mahakulkar et al., (2016) reported in Rough Lemon Fruits the results indicated that fruit volume $(150.95 \mathrm{cc})$, fruit diameter $(8.00 \mathrm{~cm})$, seed germination $(68.21 \%)$ and seed vigour (1273.35) was found better in the plants treated with $\mathrm{T}_{8}[75 \% \mathrm{RDF}(450 \mathrm{~g} \mathrm{~N}+225 \mathrm{~g}$ $\mathrm{P}_{2} \mathrm{O}_{5}+225 \mathrm{~g} \mathrm{~K} 2 \mathrm{O} /$ plant $)+500 \mathrm{~g} \mathrm{AM}$ (Actinomycetes)/plant $+100 \mathrm{~g}$ Azotobacter /plant $+100 \mathrm{~g}$ PSB/plant $+15 \mathrm{~kg}$ vermicompost/plant], whereas TSS and acidity of fruits showed non-significant results with respect to different combinations.

Kumar et al., (2018) indicated that in Lemon fruit application of $75 \%$ NPK $(315 \mathrm{~g} \mathrm{~N}+210 \mathrm{~g}$ $\mathrm{P}+315 \mathrm{~g} \mathrm{~K})+10 \mathrm{~kg} \mathrm{NC}+200 \mathrm{~g} \mathrm{PSB}+200 \mathrm{~g}$ Azotobacter found to be statistically significant and most beneficial and promotive in relation to maximum percent increase in tree height (14.44 and $15.34 \%$ ), tree spread (16.20 and $17.68 \%)$, trunk diameter (11.21 and 13.55), maximum fruit set (79.19 and $80.54 \%$ ) and fruit retention was recorded while maximum fruit drop (64.34 and $63.35 \%$ ) recorded under control treatment during 2011-12 and 2012-13, respectively.

\section{Guava}

Dheware et al., (2020) reported that Maximum flowering $(92.33 \%)$ and highest TSS $\left(10.37^{\circ} \mathrm{B}\right)$ of Guava Fruit cv. Allahabad Safeda observed under treatment $T_{4}$ containing $250 \mathrm{~g}$ PSB + Vermicompost $30 \mathrm{~kg}$ $+250 \mathrm{~g}$ Azospirillum while maximum average weight of fruits (400 g), yield of fruits $(29.60 \mathrm{~kg} /$ tree and $11.84 \mathrm{t} / \mathrm{ha})$ and lowest acidity content $(0.19 \%)$ were seen with $\mathrm{T}_{6}$ application of Vermicompost $30 \mathrm{~kg}+250$ g PSB + 250 g Azospirillum + Vermi wash foliar spray (dilution with water @ 1:1).

Sharma et al., (2013) revealed that the Guava quality and yield parameters like maximum length of fruit $(8.39 \mathrm{~cm})$, width $(7.94 \mathrm{~cm})$, pectin (0.81 per cent), weight $(244.24 \mathrm{~g})$ and yield (41.14 kg / plant) under treatment containing $75 \% \mathrm{~N}$ from inorganic $+25 \% \mathrm{~N}$ from FYM while $50 \% \mathrm{~N}$ from inorganic + $50 \% \mathrm{~N}$ from FYM + Azotobacter showed highest total sugars $(8.61 \%)$ or TSS $\left(12.95^{\circ} \mathrm{B}\right)$ and minimum physiological weight loss $(14.29 \%)$ at an interval of ten days under appropriate situations.

Binepal et al., (2013) concluded that substantially maximum length $(7.52 \mathrm{~cm})$ of Guava fruit, diameter $(7.91 \mathrm{~cm})$, volume (217.41 ml), thickness and weight of pulp $(2.46 \mathrm{~cm})$ and $(211.61 \mathrm{~g})$ and weight of seed $(8.76 \mathrm{~g})$ by the treatment of $\mathrm{T}_{9}(100 \% \mathrm{~N}+$ $\mathrm{P}_{2} \mathrm{O}_{5} 100 \%+\mathrm{PSB}+$ Azospirillum + Vermicompost $10 \mathrm{~kg}$ ) while lowest percentage of pulp (96.08 \%) were found 
under the treatment $\mathrm{T}_{10}\left(75 \% \mathrm{~N}+75 \% \mathrm{P}_{2} \mathrm{O}_{5}+\right.$ PSB + Azospirillum + Vermicompost $10 \mathrm{~kg}$ ) which was higher than control.

Shukla et al., (2009) concluded that the treatment of NPK $50 \%+250 \mathrm{~g}$ Azotobacter + $50 \mathrm{~kg} \mathrm{FYM}\left(\mathrm{T}_{7}\right)$ greatly enhances the volume of canopy $\left(201.42 \mathrm{~m}^{3}\right)$, ascorbic acid (198.30 $\mathrm{mg}$ per 100 gram pulp), weight of fruit $(153.30 \mathrm{~g})$, total sugars $(8.10 \%)$, reducing sugars $(4.77 \%)$, TSS (14\%), leaf nitrogen, phosphorus, potassium content $(1.40 \%$, $0.46 \%, 1.17 \%$, respectively) of Guava cv. Sardar. This combination of $50 \%$ NPK +250 g Azotobacter $+50 \mathrm{~kg} \mathrm{FYM}\left(\mathrm{T}_{7}\right)$ also gave considerably higher yield $(28.95 \mathrm{~kg})$ with highest B: C (2.53: 1) ratio.

Pilania et al., (2010) observed that the pruning effect with INM practice i.e. by the application of $50 \mathrm{~g} \mathrm{~N}+20 \mathrm{~g} \mathrm{P}+50 \mathrm{~g} \mathrm{~K}+$ Aspergillus niger +Azotobacter $+5 \mathrm{~kg}$ vermicompost $+25 \%$ pruning intensity $\left(\mathrm{F}_{5} \mathrm{I}_{1}\right)$ showed highest flowers per shoot (57.83), canopy volume $\left(0.96 \mathrm{~m}^{3}\right)$, while $50 \mathrm{~g} \mathrm{~N}+20 \mathrm{~g}$ $\mathrm{P}+50 \mathrm{~g} \mathrm{~K}+$ Aspergillus niger +Azotobacter + $5 \mathrm{~kg}$ vermicompost $+75 \%$ pruning intensity $\left(\mathrm{F}_{5} \mathrm{I}_{3}\right)$ gave maximum diameter of fruit 5.31 $\mathrm{cm}$, weight of fruit $(158.06 \mathrm{~g})$, pulp seed ratio and weight (39.93 and $154.19 \mathrm{~g}$ ) in both years. However, maximum area of leaf (59.46 $\left.\mathrm{cm}^{2}\right)$ and yield $(6.68 \mathrm{~kg} /$ plant and $33.43 \mathrm{t} / \mathrm{ha})$ comes with $50 \mathrm{~g} \mathrm{~N}+20 \mathrm{~g} \mathrm{P}+50 \mathrm{~g} \mathrm{~K}+$ Aspergillus niger +Azotobacter $+5 \mathrm{~kg}$ vermicompost + pruning intensity $50 \%\left(\mathrm{~F}_{5} \mathrm{I}_{2}\right)$ with $\mathrm{B}: \mathrm{C}$ (4.33) ratio.

Jamwal et al., (2018) reported that the maximum tree height $(21.99 \%)$, canopy spread N-S $(23.57 \%)$ and E-W direction $(23.50 \%)$ of Guava fruit obtained with the application of Azotobacter $+(100 \%$ Nitrogen through urea) $\mathrm{T}_{11}$, whereas maximum number of fruits/tree (21), Maximum average fruit weight (190.10gm), Maximum length of fruit $(7.10 \mathrm{~cm})$, diameter $(7.15 \mathrm{~cm})$, volume (192.13), yield/tree $(3.99 \mathrm{Kg})$, Fruit yield/ha
(199.58 q) has been obtained with treatment $\mathrm{T}_{14}$ Azotobacter $+(75 \%$ Nitrogen through urea + Vermicompost $25 \%$ ).

Singh et al., (2018) indicated that the treatment containing $75 \% \mathrm{RDF}+\mathrm{FYM} 40 \mathrm{Kg}$ /tree $\left(\mathrm{T}_{3}\right)$ recorded maximum plant height $(0.64 \mathrm{~m})$, trunk girth $(5.46 \mathrm{~cm})$, tree canopy spread increment $(0.46 \mathrm{~m})$, number of leaves and branches per shoot (7.29) and (12.56), selected shoot length $(26.90 \mathrm{~cm})$ and diameter $(4.26 \mathrm{~cm})$, fruit numbers $(307.32)$, number of flowers (617.09), fruit set $(49.80 \%)$, yield $(54.27 \mathrm{~kg} /$ plant or $8.68 \mathrm{t} / \mathrm{ha})$ in Guava cv. L49 as compared to other treatments and minimum parameters seen under control $\left(\mathrm{T}_{1}\right)$ during both years on pooled basis.

\section{Sapota}

Sheik et al., (2019) concluded highest yield of Sapota trees (70.04 and $64.27 \mathrm{~kg} /$ plant), ascorbic acid (2.85 and $2.69 \mathrm{mg} / 100 \mathrm{~g})$, total sugar $(18.35 \%$ and $18.19 \%)$, reducing sugar $(13.10 \%$ and $13.02 \%)$ and non-reducing sugar content $(5.25 \%$ and $5.17 \%)$ for first and second season respectively were observed under the application of $\mathrm{T}_{8} \mathrm{RDF}(1000: 1000$ : 1500 g NPK/tree) + vermicompost @ 12.5 $\mathrm{kg} /$ tree + EM (effective microorganisms). This was followed by the treatment $\mathrm{T}_{7}(\mathrm{FYM}$ @ $50 \mathrm{~kg} /$ tree + RDF + EM 1:250 dilution). The lowest values except acidity were obtained in control treatment.

Meena et al., (2019) reported that application of 2/3rd part of RDF $+250 \mathrm{~g}$ Azotobacter + $250 \mathrm{~g}$ Azospirillum $+50 \mathrm{~kg}$ FYM plant $^{-1}$ $\left(\mathrm{T}_{11}\right)$ considerably increases the yield $(29.03$ $\mathrm{kg} /$ tree) and number of fruits (327.88) per plant whereas all yield parameters were observed minimum under control. Baviskar et al., (2011) reported that in Sapota fruits number obtained/plant (1569.33) and yield (197.53 kg/plant) were seen highest in those plants which are given by the application of $\mathrm{T}_{9}(1125 \mathrm{~g} \mathrm{~N}: 750 \mathrm{~g} \mathrm{P}: 375 \mathrm{~g} \mathrm{~K}+250$ gm PSB 
+250 gm Azotobacter + vermicompost 15 $\mathrm{kg})$.

The fruit quality contributing factors viz., fruit volume $(117.20 \mathrm{cc})$, weight $(125.87 \mathrm{~g})$, pulp and peel weight (101.66 g) and (22.50 g), total sugars $(4.24 \%)$ and $\operatorname{TSS}\left(23.16^{\circ} \mathrm{B}\right)$ with minimum amount of acidity $(0.220 \%)$ comes under the same treatment. However, minimum fruit volume $(45.00 \mathrm{cc})$, weight $(61.33 \mathrm{~g})$, length $(3.30 \mathrm{~cm})$, pulp and peel weight $(61.33 \mathrm{~g})$ and $(10.63 \mathrm{~g})$, breadth (3.33 $\mathrm{cm})$ and yield $(73.99 \mathrm{~kg} /$ plant $)$ were recorded under the treatment $\mathrm{T}_{11}$ (control).

Tasleema et al., (2019) observed that the trees which received the application of RDF + vermicompost @ $12.5 \mathrm{~kg}$ tree/ + EM had recorded the tallest plant height $(7.29 \mathrm{~m})$, plant spread $(7.19 \mathrm{~m}$ in E-W and $7.20 \mathrm{~m}$ in $\mathrm{N}-$ $\mathrm{S})$ and the maximum canopy volume of 96.49 $\mathrm{m}^{3}$.

\section{Plum}

Kamatyanatti et al., (2019) observed in Plum cv. Kala Amritsari the maximum height of plant $(0.27 \mathrm{~m})$, rise in height percentage (4.91 $\%)$, area of leaf $\left(13.13 \mathrm{~cm}^{2}\right)$, chlorophyll (23.88) index and annual growth of shoot $(70.63 \mathrm{~cm})$ were seen in the $\mathrm{T}_{11}$ treatment containing $(\mathrm{N} 75 \%+12.5 \% \mathrm{~N}$ by FYM + $12.5 \% \mathrm{~N}$ by vermicompost + bio-fertilizers) followed by $\mathrm{T}_{9}$ ( $75 \%$ of $\mathrm{N}+$ bio-fertilizers + $25 \% \mathrm{~N}$ through FYM) and lowest height were seen in $\mathrm{T}_{1}$ (Control) i.e. $0.14 \mathrm{~m}$. While maximum fruit yield $(52.14 \mathrm{~kg} / \mathrm{tree})$ was reported under $\mathrm{T}_{11}$ and minimum in $\mathrm{T}_{2}(50 \%$ of $\mathrm{N}+50 \% \mathrm{~N}$ through $\mathrm{FYM}$ ) which was $(38.63 \mathrm{~kg} /$ tree $)$.

\section{Litchi}

Raghavan et al., (2018) concluded that highest fruit number (1281), total sugars $(26.14 \%)$, yield $(30.01 \mathrm{~kg})$ and reducing sugar
(14.51\%) per tree of Litchi cv. Muzaffarpur was seen in 500 : 250: $250 \mathrm{~g} \mathrm{NPK}+100 \mathrm{~g}$ VAM +100 g PSM +150 g Azotobacter +100 $\operatorname{kg}$ FYM $\left(\mathrm{T}_{9}\right)$, while maximum fruit cracking recorded in control (1000 : 500 :500 g NPK). The most successful treatment of fruit yield and quality in litchi was the application of $500 \mathrm{~g} \mathrm{~N}+250 \mathrm{~g} \mathrm{P}+250 \mathrm{~g} \mathrm{~K}+100 \mathrm{~g}$ VAM +100 g PSM +150 g Azotobacter $+100 \mathrm{~kg}$ FYM (T9) in the foothills of Arunachal Pradesh.

\section{Phalsa}

Sutariya et al., (2018) revealed that the Quality attributing characters of Phalsa cv. Local viz. juice $(53.07 \%)$, TSS $\left(23.17^{\circ}\right.$ Brix $)$, total sugar $(6.55 \%)$, reducing sugar $(2.77 \%)$, ascorbic acid (38.20 mg/ $100 \mathrm{~g}$ of fresh pulp) content were significantly higher with $\mathrm{T}_{7}$ $(50 \% \mathrm{~N}$ through urea $+25 \% \mathrm{~N}$ through vermicompost per plant $+100 \mathrm{~g} \mathrm{P}_{2} \mathrm{O}_{5}$ through $\mathrm{SSP}+50 \mathrm{~g} \mathrm{~K}_{2} \mathrm{O}$ through MOP per plant + AAU PGPR consortium) and minimum acidity $(2.02 \%)$ were shown in $\mathrm{T}_{7}$ treatment.

\section{Bael}

Vishwakarma et al., (2017) reported that in Bael cv. Narendra Bael-9 the maximum fruit length $(24.00 \mathrm{~cm}$ and $24.62 \mathrm{~cm})$, fruit width $(18.08 \mathrm{~cm}$ and $19.32 \mathrm{~cm})$, fruit weight $(2.41 \mathrm{~kg} /$ fruit and $2.45 \mathrm{~kg} /$ fruit), number of seed per fruit (114.50 and 120.75), minimum shell weight $(303.44 \mathrm{~g}$ and $306.50 \mathrm{~g})$, maximum TSS $\left(35.66^{\circ}\right.$ Brix and $37.85^{\circ}$ Brix), ascorbic acid $(20.75 \mathrm{mg} / 100 \mathrm{~g}$ pulp and $21.26 \mathrm{mg} / 100 \mathrm{~g}$ pulp) and Total carotene $(55.84 \mu \mathrm{g} / 100 \mathrm{~g}$ pulp and $55.72 \mu \mathrm{g} / 100 \mathrm{~g}$ pulp) was recorded with the use of $\mathrm{T}_{7}-50 \mathrm{Kg}$ FYM $+100 \%$ NPK $+200 \mathrm{~g}$ each (Azotobacter + PSB) followed with the application of $\mathrm{T}_{8} 75 \%$ $\mathrm{NPK}+200 \mathrm{~g}$ PSB $+200 \mathrm{~g}$ Azotobacter $+50 \mathrm{Kg}$ FYM in comparison to other treatments over the two experimental years. 


\section{Walnut}

Bhattarai and Tomar (2009) stated that the $\mathrm{RDF}$ of NPK $+50 \mathrm{~kg}$ vermicompost and $3 / 4$ $\mathrm{NPK}+$ vermicompost $68.75 \mathrm{~kg}$ were successful in enhancing the leaf nutritional status of Walnut.

\section{Pineapple}

Baraily and Deb (2018) observed the treatment $\mathrm{T}_{9}(75 \% \mathrm{RDF}$ of $\mathrm{NPK}+$ biofertilizer +7.5 t/ha Vermicompost) recorded significantly maximum in fruit length without crown $(21.92 \mathrm{~cm})$, crown length $(14.91 \mathrm{~cm})$, crown weight $(170.7 \mathrm{~g})$, estimated yield without crown (63.41t/ha), fruit juice content $(0854.8 \mathrm{~g})$, TSS $\left(13.56^{\circ} \mathrm{Brix}\right)$, reducing sugar $(5.77 \%)$ which closely related by $\mathrm{T}_{8}(100 \%$ of $\mathrm{RDF}$ of NPK + bio-fertilizer $+5 \mathrm{t} / \mathrm{ha}$ Vermicompost).

\section{Strawberry}

Umar et al., (2008) observed that highest yield (i.e.372.89q per ha) comes by the treatment of fully $\mathrm{N}$ from urea + Azotobacter while second yield (i.e.358.43 q per ha) were seen by the treatment of $75 \% \mathrm{~N}$ as urea + $25 \% \mathrm{~N}$ as FYM + Azotobacter were closely related to each other.

Nazir et al., (2015) recorded the observations on growth characters like maximum height of plant $(23.39 \mathrm{~cm})$, runners/plant $(13.03)$ and plant spread $(24.21 \mathrm{~cm})$ were in treatment $\mathrm{PSB}+$ wood ash + Azotobacter + poultry manure + mustard oil cake and this treatment also improves yield (238.95g) and physical fruit characters like diameter, length, weight and volume $(3.11 \mathrm{~cm}, 3.95 \mathrm{~cm}, 11.11 \mathrm{~g}, 20.39$ $\mathrm{cm}^{3}$, respectively) and chemical characters like $\operatorname{TSS}\left(9.01^{\circ} \mathrm{B}\right)$, total sugars $(7.95 \%)$ and acidity $(0.857 \%)$ content.
Bhagat and Panigrahi (2020) observed the flowering and physical parameters of fruit i.e. number of flowers (43.41), number of fruits $(41.80 /$ plant $)$, diameter $(4.85 \mathrm{~cm})$, length $(6.64 \mathrm{~cm})$, volume $(37.17 \mathrm{cc})$, weight of fruit $(43.33 \mathrm{~g})$ and fruit yield (355.84 q/ha) were significantly influenced under the treatment $\mathrm{T}_{11}$ : (RDF + Azospirillum (@7 kg / ha) + Phosphate Solubilizing Bacteria (@6 kg / ha) + VAM (@10 kg / ha) whereas, the minimum value for the same was observed under control $\left(\mathrm{T}_{0}\right)$. Similarly, highest benefit cost ratio registered in the same treatment (4.20:1), while the lowest value (2.20:1) was observed in $\mathrm{RDF}+$ control.

\section{Conclusion is as follows:}

In order to optimize yield capacity, constant and inconsistent usage of chemical fertilizers in a disequilibrium ratio contributes to a decrease in soil productivity as well as plant yield production resulting in either stagnation or decrease in yield. Chemical fertilization has certainly improved crop production but to a larger extent it may lead to soil erosion and creates soil health issues, whereas the use of organic manures alone without inorganic fertilizers could not be able to fulfill the requirement of high nutrient demanding crops due to the bulk and slow-acting nature of these organic fertilizer sources. Use of biofertilizers which are cheaper and pollution free for increasing crop productivity have great potential in current day agriculture. But, it is very difficult to manage all the nutrient needs through organic manures and biofertilizers. Hence, from the above study the result is concluded that it is advisable to supply $50 \%$ of the nutrients requirement through inorganic fertilizers and rest from the organic sources. Thus, the Integrated Nutrient Management approach may help in boosting the crop production by synergistic effects and also helps in maintaining the soil conditions. 


\section{References}

Acevedo, I. C., and Pire, R. (2004). Effects of vermicompost as substrate amendment on the growth of papaya (Carica papaya L.). Interciencia, 29(5), 274-279.

Alam, S., and Seth, R. K. (2014). Comparative study on Effect of Chemical and Biofertilizer on Growth, Development and Yield Production of Paddy crop (Oryza sativa). International Journal of Science and Research, 3(9), 411-414.

Athani, S. I., and Hulamani, N. C. (2000). Effect of vermicompost on fruit yield and quality of banana cv. Rajapuri (Musa AAB). Karnataka Journal of Agricultural Sciences, 13(4), 942-946.

Athani, S. I., Ustad, A. I., Prabhuraj, H. S., Swamy, G. S. K., Patil, P. B., and Kotikal, Y. K. (2005, December). Influence of vermi-compost on growth, fruit yield and quality of guava cv. Sardar. In $I$ International Guava Symposium 735 (pp. 381-385).

Bakshi, M., Wali, V. K., and Sharma, D. (2018). Growth, yield and quality of Kinnow mandarin as affected by integrated nutrient management. Annals of Biology, 34(2), 202-206.

Baraily, P., and Deb, P. (2018). Influence of integrated nutrient management on yield and bio-chemical parameters of pineapple (cv. Kew). Journal of Pharmacognosy and Phytochemistry, 7(5), 1339-1342.

Baviskar, M. N., Bharad, S. G., Dod, V. N., and Barne, V. G. (2011). Effect of integrated nutrient management on yield and quality of sapota. Plant Archives, 11(2), 661-663.

Bhagat, P., and Panigrahi, H. Effect of biofertilizers on growth, yield and quality of strawberry (Fragaria $x$ ananassa Duch.) cv. Nabila under net tunnel (Doctoral dissertation, Indira Gandhi Krishi Vishwavidyalaya, Raipur).

Bhalerao, V. P., Patil, N. M., Badgujar, C. D., and Patil, D. R. (2009). Studies on integrated nutrient management for tissue cultured Grand Naine banana. Indian Journal of Agricultural Research, 43(2), 107-112.

Bhattarai, B. P., and Tomar, C. S. (2009). Effect of integrated nutrient management on leaf nutrient status of walnut (Juglans regia L.). Nepal Journal of Science and Technology, 10, 63-67.

Binepal, M. K., Tiwari, R., and Kumawat, B. R. (2013). Effect of integrated nutrient management on physico-chemical parameters of guava under Malwa Plateau conditions of Madhya Pradesh. Annals of Plant and Soil Research, 15(1), 47-49.

Dheware, R. M., Nalage, N. A., Sawant, B. N., Haldavanekar, P. C., Raut, R. A., Munj, A. Y., and Sawant, S. N. (2020). Effect of different organic sources and biofertilizers on guava (Psidium guajava L.) cv. Allahabad safeda. Journal of Pharmacognosy and Phytochemistry, 9(2), 94-96.

Gajbhiye, B. R., Patil, V. D., and Kachave, T. R. (2020). Effect of integrated nutrient management on growth and yield of pomegranate (Punica granatum L.). Journal of Pharmacognosy and Phytochemistry, 9(4), 1703-1706.

Gaur, A. C. (2001). Organic manure: A basic input in organic farming. Indian Farming, 51(3), 3-11.

Gautam, U. S., Singh, R., Tiwari, N., Gurjar, P. S., and Kumar, A. (2012). Effect of integrated nutrient management in mango cv. Sunderja. Indian Journal of Horticulture, 69(2), 151-155.

Ghosh, A., Dey, K., Bhowmick, N., and Dey, A. N. (2020). Reproductive Behaviour of Lemon (Citrus limon Burm.) Affected by Different Pruning Intensities and Integrated Nutrient Management Under Various Growing Seasons. National Academy Science Letters, 43(1), 81-84.

Hasan, M. A., Manna, M., Dutta, P., Bhattacharaya, K., Mandal, S., Banerjee, H. and Jha, S. (2013). Integrated nutrient management in improving fruit quality of mango 'Himsagar'. Acta Horticulturae, (992), 167-172.

Hasan, M. A., Manna, M., Dutta, P., Bhattacharaya, K., Mandal, S., Banerjee, H., ... and Jha, S. (2013). Integrated nutrient management in improving fruit quality of mango 'Himsagar'. Acta Horticulturae, (992), 167-172.

Hazarika, B. N., and Ansari, S. (2007). 
Biofertilizers in fruit crops-A review. Agricultural Reviews, 28(1), 69-74.

Jamwal, S., Mishra, S., and Singh, S. (2018). Effect of integrated nutrient management on physical characteristics of Guava under Meadow Orcharding CV. Allahabad Safeda. Journal of Pharmacognosy and Phytochemistry, 2076-2079.

Jat, L. K., Singh, Y. V., Meena, S. K., Meena, S. K., Parihar, M., Jatav, H. S. and Meena, V. S. (2015). Does integrated nutrient management enhance agricultural productivity. J Pure Appl Microbiol, 9(2), 1211-1221.

Kamatyanatti, M., Kumar, A., and Dalal, R. P. S. (2019). Effect of integrated nutrient management on growth, flowering and yield of subtropical plum cv. Kala Amritsari. Journal of Pharmacognosy.

Kanwar, A., Sahu, G. D., and Panigrahi, H. K. (2020). Impact of integrated nutrient management on yield and quality parameters of papaya (Carica papaya L.) Cv. Red Lady under net house. Journal of Pharmacognosy and Phytochemistry, 9(3), 1443-1445.

Kumar, S., Kundu, M., and Rakshit, R. (2019). Effect of bio-fertilizer on growth, yield and quality of strawberry (Fragariax ananassa Duch.) cv. Camarosa. Bull. Env. Pharmacol. Life Sci, 8, S99-S107.

Kumar, T. B., Kumar, G. P., Kumar, R. S., and Muruganandam, C. (2020). Effect of nutrient management through bio-organic manures on fruit setting, fruit drop and fruit retention of acid lime (Citrus aurantifolia Swingle). Plant Archives, 20(1), 1570-1572.

Kumar, V., Malik, S., Dev, P., Kumar, M., Singh, M., and Mohan, B. (2018). Effect of integrated nutrient management in relation to vegetative parameters of lemon (Citrus limon burm) CV. pant Lemon-1 in sandy loam soil under Western Uttar Pradesh Conditions. Progressive Agriculture, 18(2), 236-239.

Kuttimani, R., Velayudham, K., Somasundaram, E., and Jothi, N. J. (2013). Effect of integrated nutrient management on corm and root growth and physiological parameters of banana. Int. J. Adv. Res, 1,
46-55.

Lal, G., and Dayal, H. (2014). Effect of integrated nutrient management on yield and quality of acid lime (Citrus aurantifolia Swingle). African Journal of Agricultural Research, 9(40), 2985-2991.

Mahajan, A., and Gupta, R. D. (2009). Integrated nutrient management (INM) in a sustainable rice-wheat cropping system. Springer Science and Business Media.

Mahakulkar, R. N., Joshi, P. S., Satkar, K., and Daberao, M. (2016). Effect of integrated nutrient management on seed germination and fruit quality of rough lemon. Current Advances in Agricultural Sciences (An International Journal), 8(1), 112-113.

Mahmoud, S. O., and Gad, D. A. M. (2020). Effect of vermicompost as fertilizer on growth, yield and quality of bean plants (Phaseolus vulgaris L.). Middle East J, 9(1), 220-226.

Mahmud, M., Ramasamy, S., Othman, R., Abdullah, R., and Yaacob, J. S. (2019). Effect of Vermicompost Application on Bioactive Properties and Antioxidant Potential of MD2 Pineapple Fruits. Agronomy, 9(2), 97.

Marathe, R. A., Bharambe, P. R., Rajvir, S., and Sharma, U. C. (2009). Soil properties of Vertisol and yield of sweet orange (Citrus sinensis) as influenced by integrated use of organic manures, inorganic and biofertilizers. Indian journal of agricultural sciences, 79(1), 3-7.

Meena, H. R., Somasundaram, J., Kaushik, R. A., Sarolia, D. K., Singh, R. K., and Meena, G. L. (2019). Integrated Nutrient Management Affects Fruit Yield of Sapota (Achras zapota L.) and Nutrient Availability in a Vertisol. Communications in Soil Science and Plant Analysis, 50(22), 2848-2863.

Meena, R. S., Ramawatar, K., Meena, V. S., and Ram, K. (2013). Effect of organic and inorganic source of nutrients on yield, nutrient uptake and nutrient status of soil after harvest of greengram. An Asian J Soil Sci, 8, 80-83.

Meena, V. S., Maurya, B. R., Verma, R., and Meena, M. D. (2013). Effect of wellgrow manure and chemical fertilizers on soil fertility and productivity of rice. 
BIOINFOLET-A Quarterly Journal of Life Sciences, 10(3b), 959-961.

Nayyer, M. A., Tripathi, V. K., Kumar, S., Lal, D., and Tiwari, B. (2014). Influence of Integrated Nutrient Management on growth, yield and quality of tissue cultured banana (Musax paradisiaca) cv Grand Naine. Indian Journal of Agricultural Sciences, 84(6), 680-683.

Nazir, N., Kumar, A., Khalil, A., and Bandey, S. A. (2015). Effect of integrated organic nutrient management on fruit yield and quality of strawberry cv Senga Sengana. International Journal of Farm Sciences, 5(2), 83-89.

Nehete, D. S., and Jadav, R. G. (2019). Effect of bio-fertilizers in combination with chemical fertilizers on flowering, yield and quality of mango (Mangifera indica L.) cv. Amrapali. Journal of Pharmacognosy and Phytochemistry, 8(4), 2934-2938.

Patil, V. K., and Shinde, B. N. (2013). Studies on integrated nutrient management on growth and yield of banana cv. Ardhapuri (Musa AAA). Journal of Horticulture and Forestry, 5(9), 130-138.

Pilania, S., Shukla, A. K., Mahawer, L. N., Sharma, R., and Bairwa, H. L. (2010). Standardization of pruning intensity and integrated nutrient management in meadow orcharding of guava (Psidium guajava). Indian Journal of Agricultural Sciences, 80(8), 673.

Poonia, K. D., Bhatnagar, P., Sharma, M. K., and Singh, J. (2018). Efficacy of biofertilizers on growth and development of mango plants cv. Dashehari. J Pharmac. and Phytochem, 7(5), 2158-2162.

Raghavan, M., Hazarika, B. N., Das, S., Ramjan, M., and Langstieh, L. B. (2018). Integrated nutrient management in litchi (Litchi chinensis Sonn.) cv. Muzaffarpur for yield and fruit quality at foothills of Arunachal Pradesh. IJCS, 6(3), 2809-2812.

Rai, K. M. (2014). Studies on integrated nutrient management in mango (Mangifera indica L.) cv. Dashehari (Doctoral dissertation, GB Pant University of Agriculture and Technology, Pantnagar-263145 (Uttarakhand)).

Saikia, P., Bhattacharya, S. S., and Baruah, K. K.
(2015). Organic substitution in fertilizer schedule: Impacts on soil health, photosynthetic efficiency, yield and assimilation in wheat grown in alluvial soil. Agriculture, Ecosystems and Environment, 203, 102-109.

Sharma, A., Wali, V. K., Bakshi, P., and Jasrotia, A. (2013). Effect of integrated nutrient management strategies on nutrient status, yield and quality of guava. Indian Journal of Horticulture, 70(3), 333-339.

Sharma, R., Jain, P. K., and Sharma, T. R. (2016). Improvement in productivities and profitability in high density orchard of mango (Mangifera indica L) cv. Amrapali through integrated nutrient. Economic Affairs, 61(3), 533-538.

SHEIK, R. T., KAMALAKANNAN, S., RAJESWARI, R., and SUDHAGAR, R. (2019). Effect of integrated nutrient management on fruit quality in sapota (Manilkara zapota (L.) P. Royen. Annals of Plant and Soil Research, 21(1), 67-70.

Shukla, A. K., Sarolia, D. K., Kumari, B., Kaushik, R. A., Mahawer, L. N., and Bairwa, H. L. (2009). Evaluation of substrate dynamics for integrated nutrient management under high density planting of guava cv. Sardar. Indian Journal of Horticulture, 66(4), 461-464.

Singh Kirad, K., Barche, S., and Singh, D. B. (2008b, December). Integrated nutrient management in papaya (Carica papaya L.) cv. Surya. In II International Symposium on Papaya 851 (pp. 377-380).

Singh, J. K., and Varu, D. K. (2013). Effect of integrated nutrient management in papaya (Carica papaya L.) cv. Madhubindu. Asian Journal of Horticulture, 8(2), 667-670.

Singh, J. P., Chaudhary, M., Tomar, S., and Shukla, I. N. (2018). Assess the effect of integrated nutrient management on growth and yield parameters of Guava cv. L-49. IJCS, 6(3), 676-680.

Singh, R., Sharma, R. R., Kumar, S., Gupta, R. K., and Patil, R. T. (2008a). Vermicompost substitution influences growth, physiological disorders, fruit yield and quality of strawberry (Fragaria $\mathrm{x}$ ananassa Duch.). Bioresource Technology, 99(17), 8507-8511. 
Singh, S. K., Shahi, S. K., Singh, D. K., and Meena, V. S. (2014). Soil Properties and Productivity of Rice (Oryza sativa L.) as Influenced by Urea, FYM and Biofertilizers. Ann. of Biol, 30(2), 335-339.

Singh, S. R., Banik, B. C., and Hasan, M. A. (2015). Effect of integrated nutrient management on vegetative growth and yield in mango cv. Himsagar. Journal of Horticultural Sciences, 10(1), 120-124.

Solanki, S. P. S., Sharma, N. C., Chandel, J. S., and Hota, D. (2020). Effect of Integrated Nutrient Management on Fruit Yield and Quality of Peach (Prunus persica L. Batsch) cv. July Elberta. International Research Journal of Pure and Applied Chemistry, 152-160.

Sutariya, N. K., Patel, M. J., Patel, H. A., and Vasara, R. P. (2018). Effect of integrated nutrient management on bio chemical parameters of phalsa (Grewia subinaequalis L.) cv. local. Journal of Pharmacognosy and Phytochemistry, 7(5), 408-411.

Syed, Z. (2009). Integrated nutrient management studies in Banana (cv. ARDHAPURI). Asian Journal of Horticulture, 4(1), 126130.

Talang, H. D., Dutta, P., Mukhim, C., and Patil, S. (2017). Effect of integrated nutrient management on mango (Mangifera indica L.) cv. Himsagar. Journal of Horticultural Sciences, 12(1), 23-32.

Tandel, B. M., Patel, B. N., and Patel, B. B. (2014). Effect of Integrated Nutrient Management on Growth and Physiological Parameters on Papaya cv. Taiwan Red
Lady. Trends in Biosciences, 7(16), 21752178.

Tasleema, S. R., Kamalakannan, S., Rajeswari, R., and Sudhagar, R. (2019). Effect of integrated nutrient management on growth characters in sapota. Plant Archives, 19(1), 1086-1088.

Umar, I., Wali, V. K., Kher, R., and Sharma, A. (2008). Impact of integrated nutrient management on strawberry yield and soil nutrient status. Applied Biological Research, 10(1 and2), 22-25.

Vishwakarma, G., Yadav, A. L., Kumar, A., Singh, A., and Kumar, S. (2017). Effect of Integrated Nutrient Management on Physico-Chemical Characters of Bael (Aegle marmelos Correa) cv. Narendra Bael-9. Int. J. Curr. Microbiol. App. Sci, 6(6), 287-296.

Wu, W., and Ma, B. (2015). Integrated nutrient management (INM) for sustaining crop productivity and reducing environmental impact: A review. Science of the Total Environment, 512, 415-427.

Yadav, A. K., Singh, J. K., and Singh, H. K. (2011). Studies on integrated nutrient management in flowering, fruiting, yield and quality of mango cv. Amrapali under high density orcharding. Indian Journal of Horticulture, 68(4), 453-460.

Zonayet, M., Paul, A. K., and Ahmed, M. (2020). Effects of Integrated Nutrient Management on the Performance of Mango on Hills in Three Districts, Bangladesh. Asian Journal of Soil Science and Plant Nutrition, Pp. 17.

\section{How to cite this article:}

Ritik Chawla and Ramesh Kumar Sadawarti. 2020. Effect of Integrated Nutrient Management on Vegetative Growth, Fruit Yield and Quality of Fruit Crops. Int.J.Curr.Microbiol.App.Sci. 9(10): 2222-2235. doi: https://doi.org/10.20546/ijcmas.2020.910.269 